\title{
Rapid marine deglaciation: asynchronous retreat dynamics between the Irish Sea Ice Stream and terrestrial outlet glaciers
}

\author{
H. Patton ${ }^{1}$, A. Hubbard ${ }^{1}$, T. Bradwell ${ }^{2}$, N. F. Glasser ${ }^{1}$, M. J. Hambrey ${ }^{1}$, and C. D. Clark $^{3}$ \\ ${ }^{1}$ Institute of Geography and Earth Sciences, Aberystwyth University, Aberystwyth, SY23 3DB, UK \\ ${ }^{2}$ British Geological Survey, Murchison House, West Mains Road, Edinburgh, EH9 3LA, UK \\ ${ }^{3}$ Department of Geography, University of Sheffield, Sheffield, S10 2TN, UK
}

Correspondence to: H. Patton (henrypatton@gmail.com)

Received: 24 July 2013 - Published in Earth Surf. Dynam. Discuss.: 23 August 2013

Revised: 31 October 2013 - Accepted: 15 November 2013 - Published: 3 December 2013

\begin{abstract}
Understanding the retreat behaviour of past marine-based ice sheets provides vital context for accurate assessments of the present stability and long-term response of contemporary polar ice sheets to climate and oceanic warming. Here new multibeam swath bathymetry data and sedimentological analysis are combined with high resolution ice-sheet modelling to reveal complex landform assemblages and process dynamics associated with deglaciation of the Celtic ice sheet within the Irish Sea Basin. Our reconstruction indicates a nonlinear relationship between the rapidly receding Irish Sea Ice Stream and the retreat of outlet glaciers draining the adjacent, terrestrially based ice cap centred over Wales. Retreat of Welsh ice was episodic; superimposed over low-order oscillations of its margin are asynchronous outlet readvances driven by catchment-wide mass balance variations that are amplified through migration of the ice cap's main ice divide. Formation of large, linear ridges which extend at least $12.5 \mathrm{~km}$ offshore (locally known as sarns) and which dominate the regional bathymetry are attributed to repeated frontal and medial morainic deposition associated with the readvancing phases of these outlet glaciers. Our study provides new insight into ice-sheet extent, dynamics and non-linear retreat across a major palaeo-ice stream confluence zone, and has ramifications for the interpretation of recent fluctuations observed by satellites over short timescales across marine sectors of the Greenland and Antarctic ice sheets.
\end{abstract}

\section{Introduction}

The mass balance and stability of ice sheets is strongly determined by the dynamic behaviour of fast-flowing ice streams and outlet glaciers, as it is through these rapid conveyors of mass that the majority of ice flux and ultimate loss to calving and melt occur. However, our understanding of long-term stability of contemporary ice sheets is fundamentally hampered by the slow thermodynamic response and evolution of the ice-sheet system, leading to large uncertainties in the prediction of ice-sheet responses on timescales longer than the satellite-derived observational record (Hindmarsh, 1995; van der Veen, 2004; IPCC WG1, 2007; Bamber et al., 2007). Reconstruction of the complex deglaciation of palaeo-ice sheets therefore offers an opportunity to explore dynamic behaviour and interactions, providing critical insight and context to potential centennial- to millennial-scale responses of our present-day polar ice sheets and their contribution to global sea-level rise (e.g. Calov et al., 2002; Knutz et al., 2007; Greenwood and Clark, 2009; Hubbard et al., 2009).

Across the British-Irish continental shelf, high-resolution, marine based, geophysical data sets have helped to shift consensus on the maximum reconstructed extent of the last ice sheet centred over Britain and Ireland to a version that was largely marine-influenced, characterised by high dynamism and advanced asynchronously across much of the continental shelf (Bowen et al., 2002; Bradwell et al., 2008; Hubbard et al., 2009; Chiverrell and Thomas, 2010; Clark et al., 2012; 
Cofaigh et al., 2012). However, the Irish Sea Basin, host to the largest ice stream of the ice sheet, has received relatively little attention, and inferences on its advance, rapid recession, and interaction with adjacent ice accumulation centres have largely relied on sedimentological interpretations and cosmogenic isotope exposure ages taken from coastal sections (Eyles and McCabe, 1989; Huddart, 1991; Merritt and Auton, 2000; Glasser et al., 2001; Ó Cofaigh and Evans, 2001; Evans and Cofaigh, 2003; Patton and Hambrey, 2009; Van Landeghem et al., 2009; Chiverrell et al., 2013).

In this paper we present new high-resolution, multibeam echo sounder data from the eastern margin of the Irish Sea Basin that reveal submarine glacial landforms close to the former confluence zone of the Irish Sea Ice Stream and the terrestrially based Welsh Ice Cap (Fig. 1). Geomorphological mapping, in combination with previous sedimentological interpretations and numerically modelled output, are used to propose a regional reconstruction of complex ice dynamics and retreat that is driven, in part, by a response to climate variations, and also to internal flow reorganisations. Rather than treating the empirical evidence and modelling as separate exercises (or one tested against the other), here we pioneer a new approach that uses both to yield a modellinginformed empirical reconstruction of ice-sheet history.

Insight concerning the retreat of the Welsh Ice Cap, particularly so for its location at the peripheral margin of the glacierised area of Celtic Britain, is seen as a useful analogue for the future response of contemporary terrestrially based ice caps, such as those in Svalbard (Moholdt et al., 2010), Canada (Burgess and Sharp, 2004) and Iceland (Magnússon et al., 2005; Bradwell et al., 2013). Predictions of eustatic sea-level rise in the 21 st century indicate glaciers such as these will be significant contributors (e.g. Meier et al., 2007). The bathymetric data also elucidate more details of the enigmatic "sarns" (large gravel ridges) that extend into Cardigan Bay, the origins of which are still equivocal.

\subsection{Geological context}

The stark geological differences between the Irish Sea Basin and Welsh hinterland allow for relatively easy discrimination of clast provenances within glacial deposits. The Irish Sea Basin is characterised largely by Mesozoic sandstones, mudstones and limestone, while volcanic and metamorphic rocks of Neoproterozoic to Ordovician age dominate the Llŷn Peninsula in NW Wales. The Welsh mountains are composed largely of Cambro-Ordovician volcanic and clastic sedimentary rocks, flanked by extensive Silurian mudstones and sandstones.

The Llŷn Peninsula marks an important glaciological zone of confluence between the former Irish Sea Ice Stream and Welsh Ice Cap in the eastern Irish Sea Basin, where a distinction can be made between glacial sediments to the west deposited exclusively by Irish Sea ice flowing southwards (e.g. Porth Oer), and those to the east deposited solely by

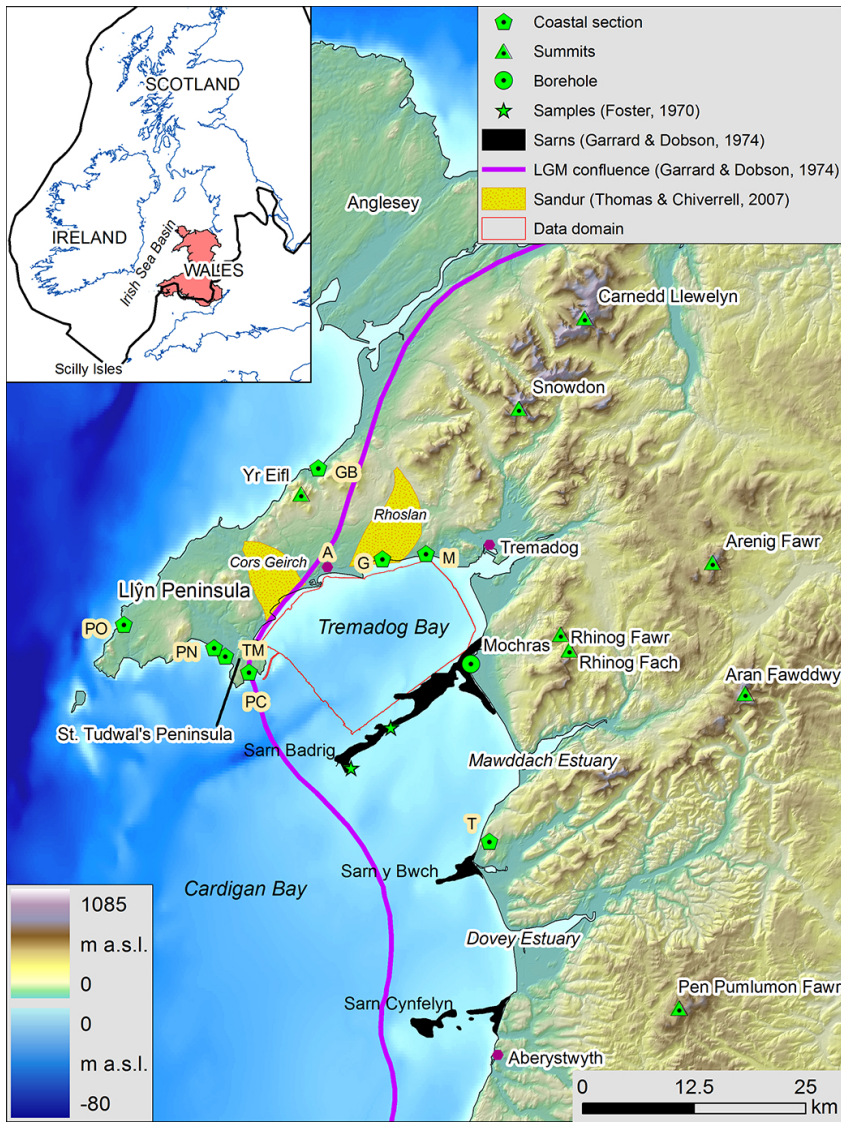

Figure 1. The terrestrially based Welsh Ice Cap, a semiindependent accumulation centre on the southern periphery of glaciation in Celtic Britain (inset box). The study area of Tremadog Bay in NW Wales, delimited in red, is bounded to the north by the Llŷn Peninsula, and Sarn Badrig to the south. Coastal sedimentological sections: Porth Oer (PO), Porth Neigwl (PN), Tai Morfa (TM), Porth Ceiriad (PC), Gwydir Bay (GB), Glanllynnau (G), Morannedd (M), and Tonfanau (T). Towns: Abererch (A). Relief is displayed using NEXTMap Britain (Intermap Technologies) data onshore, and British Geological Survey (BGS) DigBath250 bathymetry data offshore.

the Welsh Ice Cap flowing west (e.g. Morannedd) (Campbell and Bowen, 1989; Fig. 1). The exposure of Welsh-sourced till at Porth Ceiriad places an important constraint on the maximum eastward limit of Irish Sea ice on the Llŷn Peninsula (Whittow and Ball, 1970), emphasising St. Tudwal's Peninsula as an important confluence zone between Welsh and Irish Sea ice masses.

For coastal exposures in this vicinity, the history of deposition has been complicated by numerous interpretations derived over the last century, particularly in terms of the number of Irish Sea and Welsh glacial phases (even glaciations), their relative timings, and the limits of glaciation associated with each (Jehu, 1909; Smith and George, 1961; Synge, 1964; Saunders, 1968a, b; Whittow and Ball, 1970; Mitchell, 1972; Bowen, 1973a, b; Boulton, 1977). More recent and 
extensive stratigraphic description, mapping and interpretation (Thomas et al., 1998; Thomas and Chiverrell, 2007) across the Llŷn Peninsula have since established a lithostratigraphical framework, recording a set of sediment-landform assemblages that reflect rapidly changing erosional and depositional environments during ice interaction and deglaciation within a single glaciation.

An important $2 \mathrm{~km}$ section at Tonfanau has shown Irish Sea-sourced diamicton to overlie Welsh till (Patton and Hambrey, 2009). Offshore in Cardigan Bay, numerous boreholes and geophysical surveys have identified a limit of Welshsourced till broadly perpendicular to the western end of the three sarns (Garrard and Dobson, 1974; Fig. 1).

\subsection{Data collection}

High-resolution bathymetric data covering $270 \mathrm{~km}^{2}$ of Tremadog Bay were collected using a multibeam echosounder during 2006 as part of the UK Civil Hydrography Programme co-ordinated by the Maritime and Coastguard Agency. A Kongsberg 3002D $300 \mathrm{kHz}$ multibeam was used for data collection. Sound velocity data were also collected from a hull-mounted AML Smart sound velocity sensor. Attitude (heave, pitch and roll), heading and positional data were collected using an Applanix POS MV motion sensor, Ashtech GSR2200, Siemens GSM and Trimble DSU4100 Dynamic Global Positional Systems. All data were compiled on board using Kongsberg Seafloor Information Systems software. Post-acquisition data processing to remove data artefacts and prepare basic mean bathymetric and CUBE (Combined Uncertainty Bathymetric Evaluation) surfaces was conducted by the UK Hydrographic Office. The British Geological Survey carried out subsequent data processing and visualisation using Caris HIPS and SIPS, and Fledermaus software. Surface models (grids) and geotiffs of the xyz data were produced at a horizontal resolution of $7 \mathrm{~m}$. To describe the geomorphological features, a variety of different data formats were used, including acoustic backscatter (amplitude of return, essentially a proxy for seabed substrate physical properties, such as hardness and roughness), hillshaded bathymetric models, and xyz elevation data. Digital mapping of glacial landforms was carried out using ArcMap GIS software.

\section{Geomorphological mapping results}

Tremadog Bay is dominated by a generally uniform NESW trending shallow depression, bounded to the north by a large rocky platform extending from the Llŷn Peninsula. Maximum water depths recorded in the multibeam data reach $24.3 \mathrm{~m}$ below present-day sea level approximately at the midpoint in the basin. A number of landforms are clearly visible on the seabed (Fig. 2):
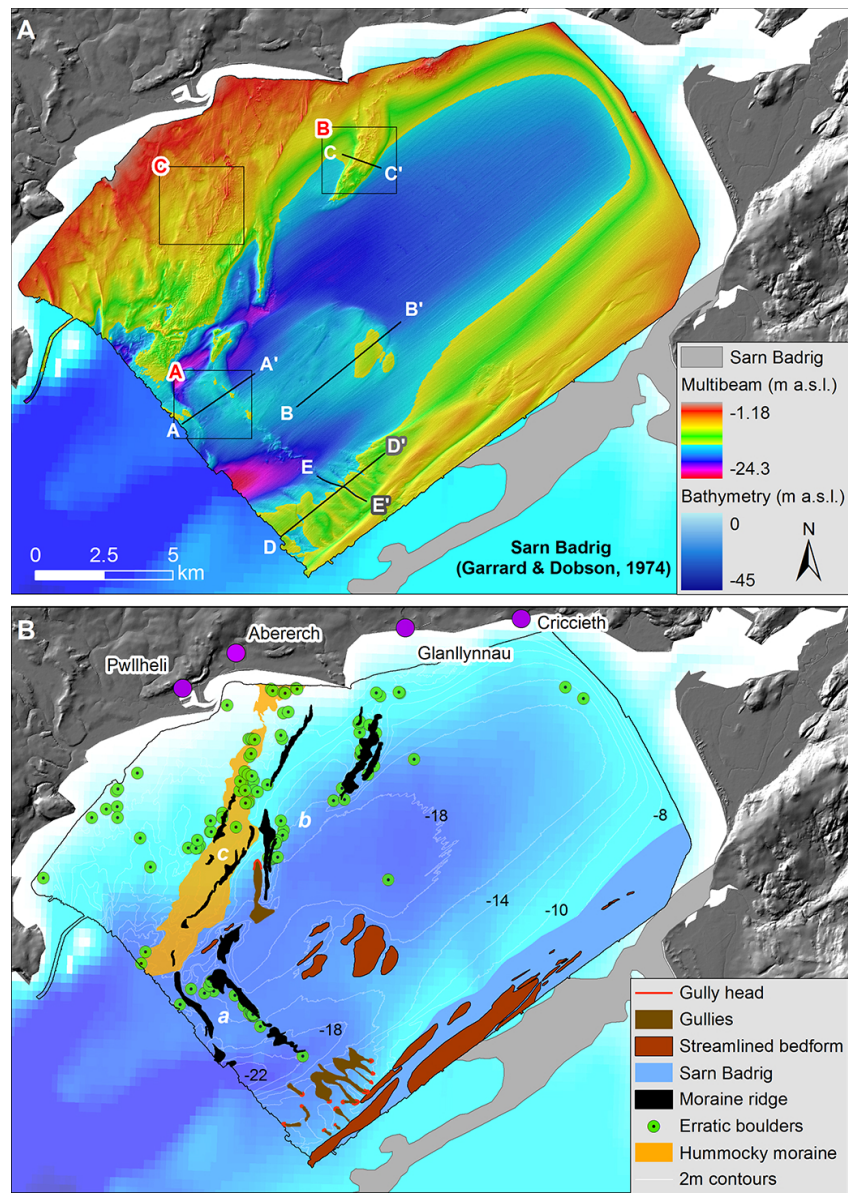

Figure 2. (A) Hillshaded high-resolution bathymetry of Tremadog Bay with locations of the transects in Fig. 3 identified. Inset boxes relate to close views of the data in Fig. 4. (B) Glacial landforms and features in Tremadog Bay are mapped from multibeam echosounder data. Interpreted moraines have been grouped according to suggested mechanisms of deposition. The grey outline of Sarn Badrig is defined from original survey results by Garrard and Dobson (1974). Contains Maritime and Coastguard Agency bathymetry data (C) Crown Copyright.

\subsection{Recessional moraines}

Moraines in the mapped site are divided into 3 sets (ac) based on their distinctive morphologies and locations (Fig. 2).

\subsubsection{Moraines: (a)}

Description. To the SW of the domain lie a number of curvilinear ridges, parallel to each other and running perpendicular to Sarn Badrig and the Llŷn Peninsula, although near the margins of the bay they turn towards the coastline following the bathymetric contours. Near Sarn Badrig, the most landward moraine changes develops a relatively strong sinuous form. Their sharp crest lines are generally gently arcuate, trending NE at their northern end. The ridges vary in 


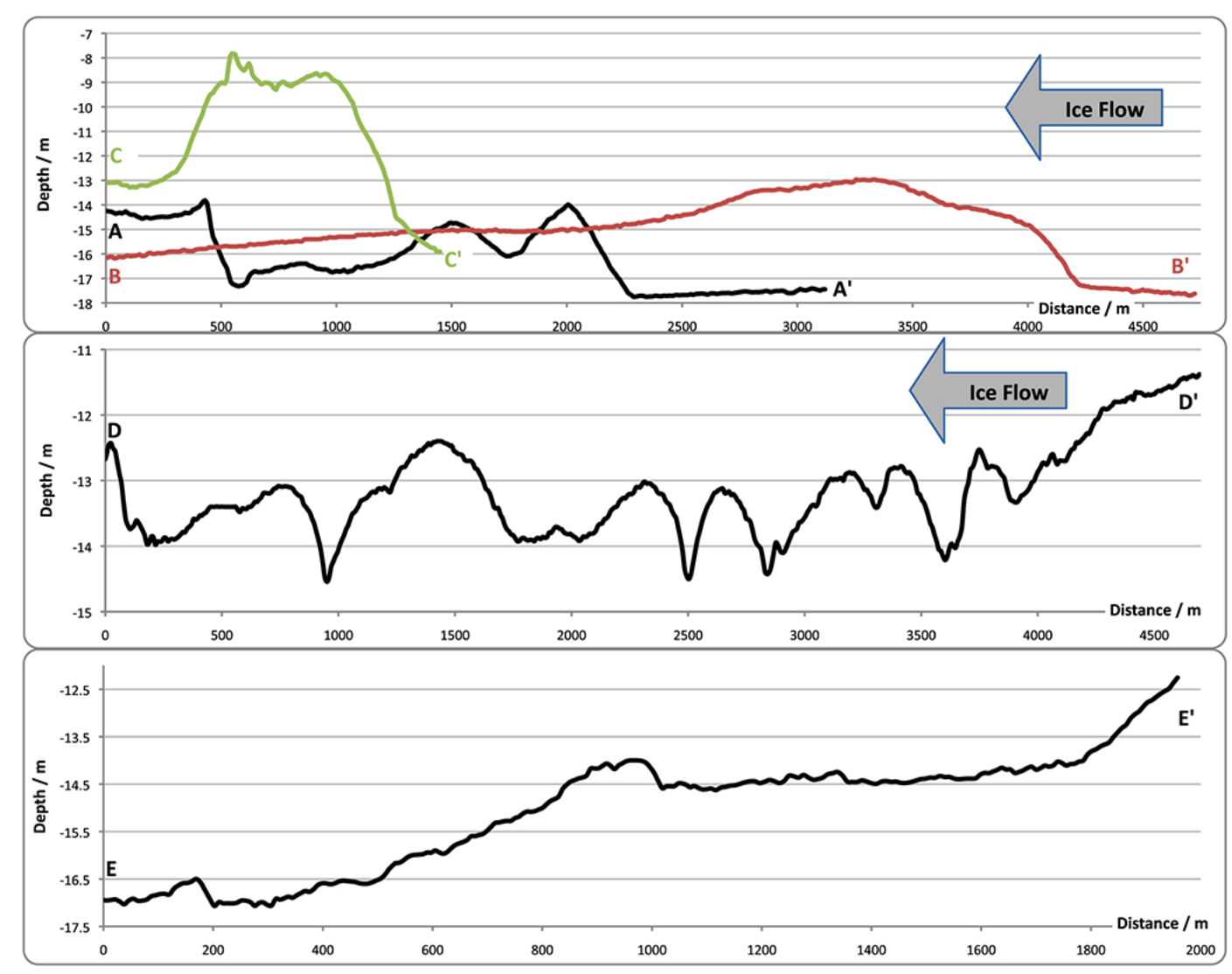

Figure 3. Vertical transects across landforms visible on the seabed of Tremadog Bay, taken from Fig. 2a. Landforms are interpreted as $\left(\mathrm{A}-\mathrm{A}^{\prime}\right)$ glaciotectonic push moraines, $\left(\mathrm{B}-\mathrm{B}^{\prime}\right)$ streamlined bedforms, $\left(\mathrm{C}-\mathrm{C}^{\prime}\right)$ frontal dump moraine, $\left(\mathrm{D}-\mathrm{D}^{\prime}\right)$ transverse profile of the gullies on Sarn Badrig, and (E-E') along-profile of one gully.

height from 3 to $5 \mathrm{~m}$ above the sea floor on their stoss side. In cross-section their profiles are asymmetrical, with the lee slopes 2-3 m higher (Fig. 3a). Associated with the ridges are a number of boulders recognisable against the subdued relief of the seabed, the majority of which are found on the distal (western) slopes of the ridges (Fig. 4a).

Interpretation. On the basis of their morphology, distribution, and setting, the curvilinear features are interpreted as end moraines associated with ice flow from the Welsh Ice Cap. Their arcuate, steep-crested, asymmetrical, and sometimes sinuous form is typical of contemporary glaciotectonic push moraines that develop during a period of positive mass balance or glacier surge (Boulton, 1986; Boulton et al., 1999; Bennett, 2001; Ottesen and Dowdeswell, 2006; Bennett and Glasser, 2009), and have been previously described in a number of other submarine environments (e.g. Ottesen and Dowdeswell, 2006; Ottesen et al., 2007; Nygård et al., 2008). The fact that these ridges are found well within the Welsh drift limit identified by Garrard and Dobson (1974) and east of exposures of Welsh till on the Llŷn Peninsula at Porth Ceiriad (Whittow and Ball, 1970) indicates that these ridges do not mark the maximum extent of Welsh glaciation, and must have been deposited following separation from Irish Sea ice during overall ice-sheet retreat.

\subsubsection{Moraines: (b)}

Description. Northeast from set (a) towards the Llŷn Peninsula are two sets of ridges slightly different in character; ridge-lines are generally less pronounced, more symmetrical (Fig. 3c), and in places appear to have undergone rotational sliding (Fig. 4b). As before, a number of boulders can be found close by, and in areas where the ridges have slumped, they can also be found on the proximal (eastern) side. The positions of these ridges may to be linked with bedrock rises around the margins of Tremadog Bay.

Interpretation. Based on their position, form, nested character, and association with numerous large boulders, these ridges are interpreted as ice-marginal moraines (e.g. Small, 1983; Benn and Evans, 2010). Structurally, the ice-proximal parts of ice-marginal moraines tend to be complex because of widespread collapse and reworking following the removal of ice support and melt out of buried ice (e.g. Benn and Owen, 2002). 


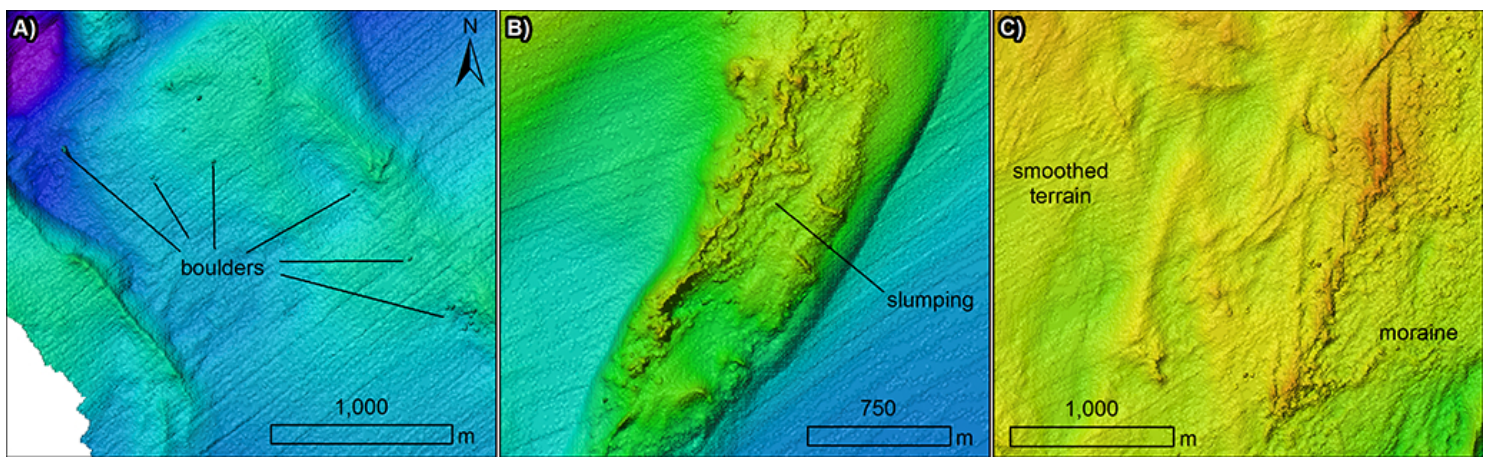

Figure 4. Magnified views of the Tremadog Bay seabed. Locations of each box are given in Fig. 2a. (A) Moraines and boulders on the western edge, $(\mathbf{B})$ slumped moraines, and $(\mathbf{C})$ contrasts between the smoothed terrain and moraine deposits to the north. Contains Maritime and Coastguard Agency bathymetry data (C) Crown Copyright.

\subsubsection{Moraines: (c)}

Description. To the northwest of the study area, running southwestwards from the coastline near Abererch, small $(<2 \mathrm{~m})$, yet extensive, linear ridges can be found associated with numerous large scattered boulders. The general topography is composed of subdued hummocky relief with an irregular surface morphology, characterised by meandering ridges and collections of mounds, up to $\sim 40 \mathrm{~m}$ wide and with no preferred orientation. Further west, the seabed dramatically changes character, becoming smooth and dissected by a number of large gullies.

Interpretation. One possibility is that the irregular and chaotic topography represented here is the remnant of a controlled hummocky moraine, with the pronounced transverse elements inherited from concentrated debris bands within the downwasting Tremadog outlet glacier (Boulton, 1972; Evans, 2009). Genetically, hummocky moraine has been used to encompass landforms with a variety of origins, including ice stagnation and englacial thrusting (cf. Hambrey et al., 1997, 1999). However, in its more restrictive sense it is used to refer to moraines deposited during the melt out of debris-mantled glaciers (Sharp, 1985; Benn and Evans, 1998). Without detailed glaciotectonic and sedimentological analyses, the term "hummocky moraine" is used here purely in its purely descriptively sense. An adjacent coastal exposure at Glanllynau, previously interpreted by Boulton (1977) as the result of stagnating ice-cored ridges, could form an important onshore equivalent of this offshore feature.

\subsection{Streamlined bedforms}

Description. In the centre of Tremadog Bay lie a number of smooth, partially oval-shaped hills (Fig. 2b). They are 3-5 m high and $2-3 \mathrm{~km}$ long with length-to-width ratios less than $50: 1$. The landforms are not associated with any obvious exposed bedrock features, and their long axes are all aligned perpendicular to the end moraines interpreted above. Similar elongated features are also present along the southern edge of the domain, overprinting the northern flank of the sarn and trending the same direction as the bedforms in the centre of the bay. The elongation ratios (length/width) of these features vary from $7: 1$ to $12: 1$.

Interpretation. Although not on the scale of mega-scale glacial lineations (e.g. Clark, 1993), without further knowledge of the subsurface components of these features they are interpreted using the non-genetic term, streamlined bedforms (cf. Ó Cofaigh et al., 2002; King et al., 2009). Their long profile - a high, blunt stoss end pointing in the upstream direction and a more gently sloping, pointed end (tail) facing down-ice (Fig. 4b) - indicates principal ice flow to be associated with Welsh-sourced ice emanating from Snowdonia and flowing into Tremadog Bay towards the southwest (Glasser and Bennett, 2004).

\subsection{Sarn Badrig}

Description. The southern edge of the data domain encroaches onto Sarn Badrig, which is an obvious topographical ridge extending at least $12.5 \mathrm{~km}$ to the SW. This substantial seabed feature divides the northern basin of Cardigan Bay (Tremadog) from the mid-basin (Mawddach), and even at its western end the sea floor in places is still only $<7.5 \mathrm{~m}$ below sea level. Our new mapping from the bathymetric data indicate that the sarn is $>4 \mathrm{~km}$ wide, almost double its previously mapped width.

Interpretation. The superimposed streamlined bedforms, combined with the high percentage of clasts it contains from the Welsh hinterland (Foster, 1970), strongly indicates a glacial origin for this broad gravel ridge. Considering the position of all three sarns in Cardigan Bay at the interfluve of major onshore valleys in West Wales (Fig. 5b), Sarn Badrig is interpreted as a large "ice-stream" interaction medial moraine - the merging of two lateral moraines (Eyles and Rogerson, 1978a). This type of moraine forms at the intersection of confluent valley glaciers below or close to the equilibrium line, and their morphological expression 


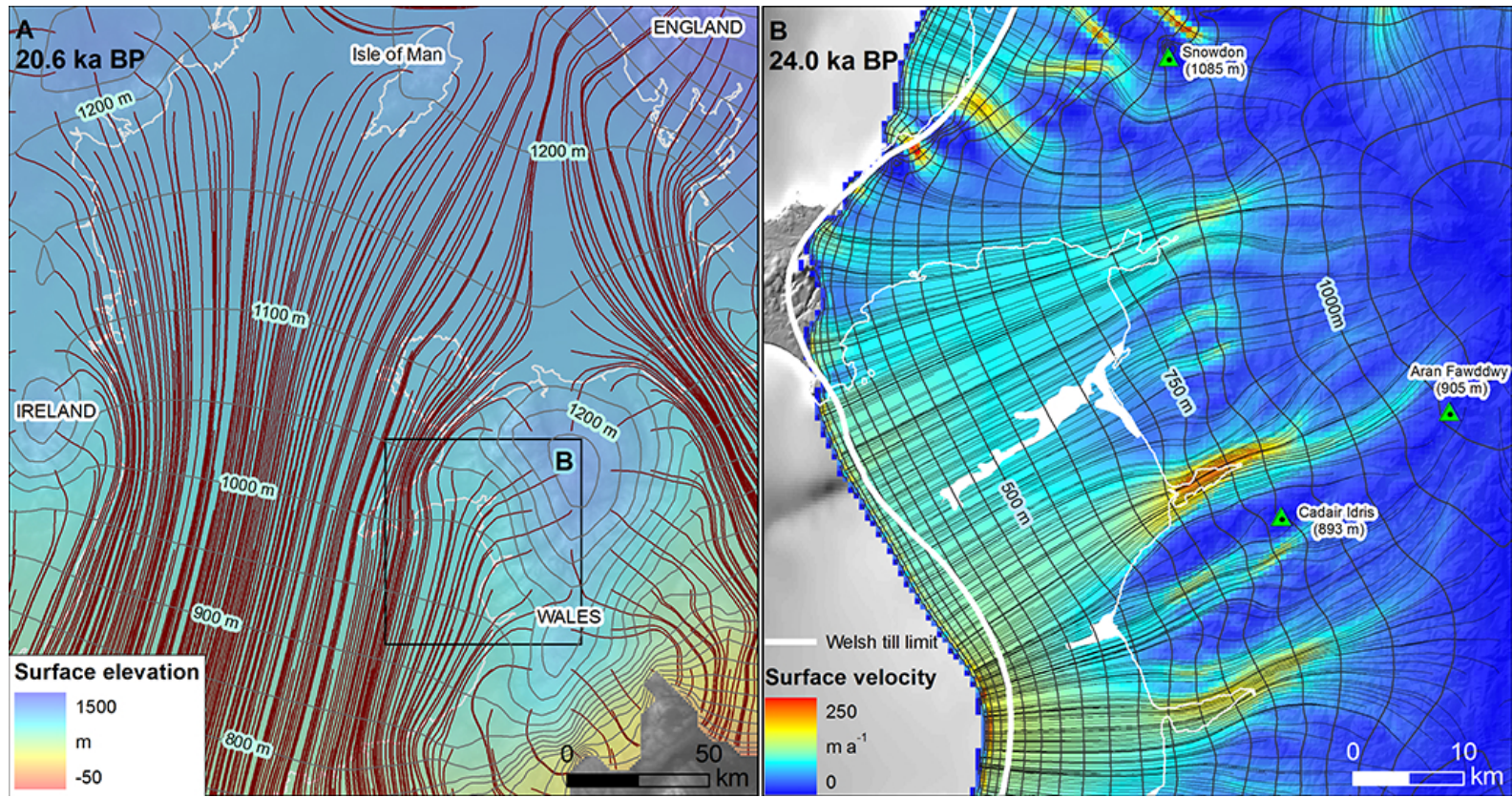

Figure 5. (A) Numerically modelled flowlines in the Irish Sea Basin and Welsh domain during the Last Glacial Maximum (LGM). Data are taken from the median experiment E109b8 by Hubbard et al. (2009). (B) Flowlines of the independently modelled Welsh Ice Cap by Patton et al. (2013a). The limit of Welsh till in Cardigan Bay was delimited by Garrard and Dobson (1974).

is influenced by the amount of available debris, with large amounts of englacial and pre-convergence subglacial debris encouraging long-lived, high-relief moraine ridges. Lateral compression between the fast-flowing glaciers forces the debris into a longitudinal septum (Smiraglia, 1989), with complex surface forms also prone to develop if the two glaciers have different velocities (Eyles and Rogerson, 1978a, b). We propose that its present submarine position accounts for much of the fines being removed, probably by a combination of wave washing and marine currents, leaving a predominantly gravel ridge, visible in places at low tide. Based on Sarn Badrig's relatively large volume $\left(\sim 1 \mathrm{~km}^{3}\right)$ and proximity to the main accumulation centres of the Welsh Ice Cap, it is speculated that the three sarns in Cardigan Bay are enduring features that have been reworked and added to over the course of numerous glaciations during the Pleistocene. This is supported by boreholes indicating "Welsh drift" over $100 \mathrm{~m}$ deep in the centre of Tremadog Bay (Garrard and Dobson, 1974), attesting to long-lived and/or rapid rates of glacigenic sediment deposition in this area.

\subsection{Parallel ridges and linear depressions}

Description. On the western flank of Sarn Badrig, approximately 10 superimposed linear depressions and parallel ridges occur orientated predominantly NW-SW. They are $\sim 200-400 \mathrm{~m}$ wide and $\sim 2 \mathrm{~m}$ deep, and contain along-profile undulations of $<0.5 \mathrm{~m}$. Gradients along the floor of the depressions are very shallow, sometimes dropping only $\sim 4 \mathrm{~m}$ over several kilometres. Morphological transects reveal a stepped profile, with a steep section on their northwestern end (Fig. 3e). The depressions and associated ridges show a distinct increase in spacing in a down-ice direction (Fig. 3d).

Interpretation. One possible interpretation is that these depressions are erosional gullies, possibly formed through a combination of (or solely by) debris flows, ice-marginal discharge, or ice-cored moraine slumping (e.g. Bennett et al., 2000). Whether these gullies represent subaerial or submarine erosion is equivocal; iceberg pits, scour marks and De Geer moraines offshore from north Wales $(>36 \mathrm{~m}$ present water depth) indicate that deglaciation of grounded Irish Sea Basin ice occurred in the presence of a proglacial water body (Van Landeghem et al., 2009). However, given that present water depths in Tremadog Bay range from 8 to $22 \mathrm{~m}$, and many coastal sections around the central and southern Irish Sea Basin have been shown to be deposited terrestrially (e.g. Thomas et al., 1998; Glasser et al., 2001; Lambeck and Purcell, 2001), we suggest that subaerial processes are more probable. A possible source for proglacial meltwater discharge on this flank of the sarn is the frontal margin of the adjacent Mawddach Glacier. With Tremadog Bay free of ice, a readvance of the adjacent Mawddach outlet lobe as far as the southern flank of Sarn Badrig could provide sufficient meltwater to have initiated erosion of these gullies. A more extensive multibeam survey and further mapping of the whole sarn would be required to test this hypothesis.

An alternative interpretation is that the intervening subparallel ridges are constructional glacigenic features. In light 


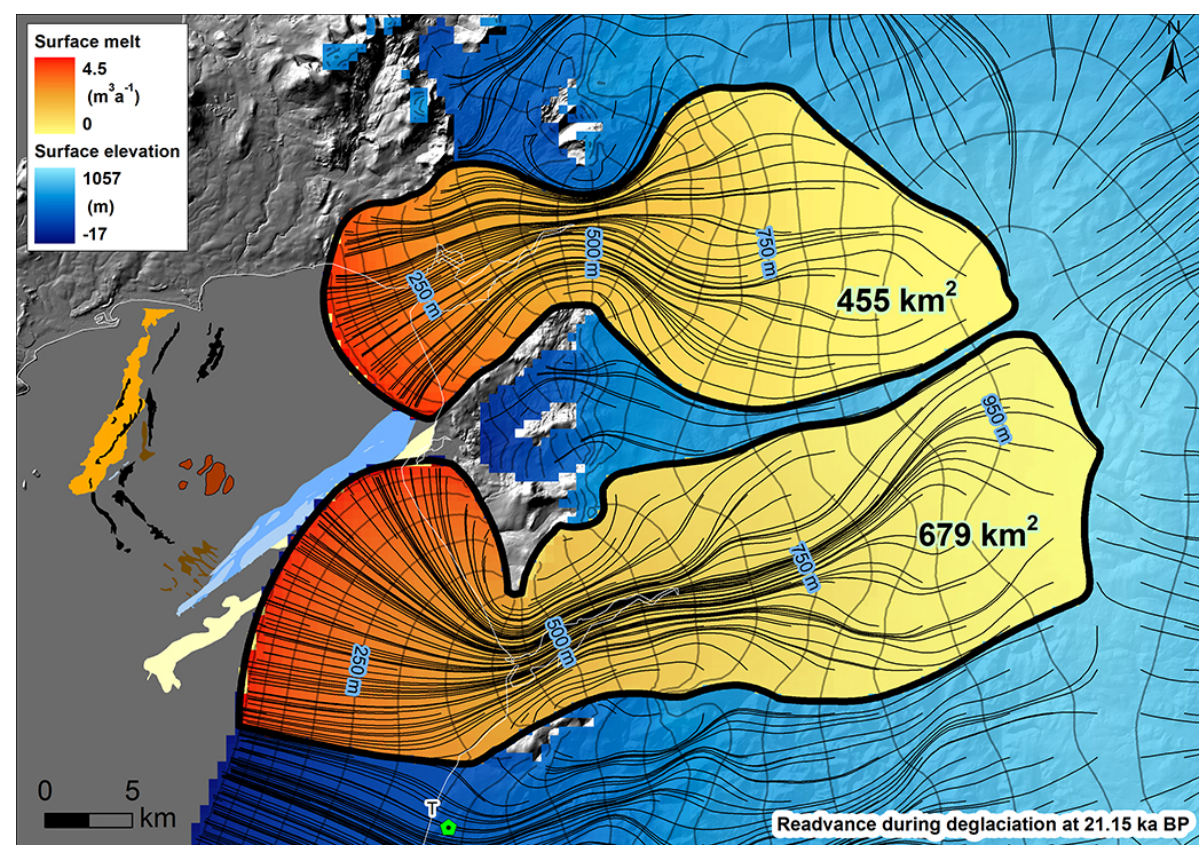

Figure 6. State of the modelled Welsh Ice Cap while readvancing during deglaciation at $21.15 \mathrm{ka}$ BP. Areal extents of the Tremadog (northern) and Mawddach (southern) Glacier catchments are highlighted. A coastal section at Tonfanau (T) records Irish Sea-sourced diamicton overlying a till of distinct Welsh origin.

of only geomorphological data, several possibilities for their formation exist: (1) closely spaced recessional moraines, laid down at the retreating margin of a large (probably landterminating) outlet glacier. Numerous analogous landforms currently exist around the margins of the present-day ice sheet and large ice caps in Greenland and Iceland (Evans and Twigg, 2002; Forman et al., 2007). (2) They could also be low-amplitude Rogen (ribbed) moraines, formed by subglacial deformation under a partially thawed or warm-based thermal regime (Lundqvist, 1989; Möller, 2006). The long axes of these short ridges align transverse to ice flow, consistent with the main Welsh ice-flow direction from Snowdonia; however their morphology is subdued and not typical of these landforms. (3) The third formation possibility is polygenetic ridges, possibly formed by ice overriding and reshaping/modifying pre-existing ice-marginal moraines. Some workers have proposed this model for sites of closely spaced transverse ridges where sedimentary structures reveal complex (polyphase) formation histories (e.g. Möller, 2006). Without knowledge of the sediment facies or structures within these submarine landforms in Tremadog Bay, their precise origin remains speculative.

\section{Comparison with modelled output}

The major benefit of numerical modelling is in its ability to describe ice masses holistically and time-transgressively. Geomorphological mapping commonly records isochronous events such as the maximum extension of the glacier ter- minus, or time-indefinite processes such as ice streaming, with little indication of glaciodynamics occurring through a glacial cycle. When viewed in combination with modelled data, however, insights concerning landscape evolution can be more objectively assessed.

High-resolution modelled output used for comparison here is taken from experiments carried out by Patton et al. (2013a, b), who modelled the independent Welsh Ice Cap during the last glacial cycle. The optimal experiment referred to in this paper, E397, was derived using a 3-D thermomechanical model and ensemble methodology, whereby the sensitivities of key individual parameters in the model were examined through the systematic perturbation of their values. "Optimal" experiments were chosen based on how well the modelled data matched key empirical constraints (e.g. margin positions, inferred retreat dates), whilst still within a realistic parameter space.

Key characteristics for the experiment E397 include a maximum temperature suppression at the Last Glacial Maximum (LGM) of $11.85^{\circ} \mathrm{C}$, combined with a precipitation reduction of $\sim 1 / 3 \mathrm{rd}$ of present-day values. Moraine limits to the east of the domain were matched by applying an enhanced west-east precipitation gradient (rain shadow effect). Post LGM, temperature and precipitation suppressions were moderately relaxed, although still kept scaled with the GISP2 climate curve. Model time slices from the northwest sector of Wales are shown in Figs. 5-7. 


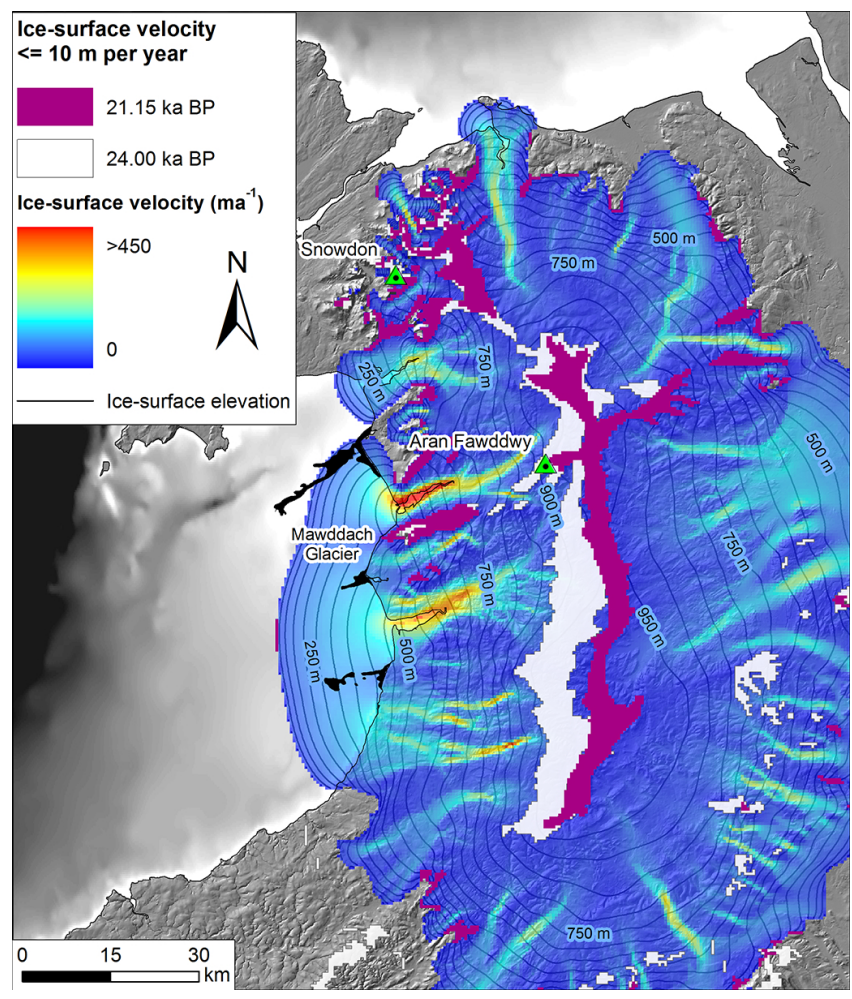

Figure 7. Modelled eastward migration of the central ice divide between 24.0 and $22.3 \mathrm{ka} \mathrm{BP}$ significantly affects the asymmetric response of the Welsh Ice Cap to renewed positive mass balance during a short-lived climatic downturn in the GISP2 forcing curve. At $22.3 \mathrm{kaBP}$ the ice divide covering Snowdonia remains static, whilst further south around Aran Fawddwy the upper reaches of the Mawddach outlet glacier catchment have notably increased.

\subsection{Ice advance}

During advance of the modelled Welsh Ice Cap, conditions conducive to fast-flowing outlet glaciers are strongly modulated by oscillations within the GISP2 record of climate forcing, and triggered by transitions to a relatively warm climate (Patton et al., 2013a, b). It is envisaged that these "purge" or fluctuation events would have led to the formation of the streamlined bedforms described in the data domain above. Figure $5 \mathrm{~b}$ shows the position of the modelled Welsh Ice Cap $500 \mathrm{yr}$ before its glacial maximum. Of particular note from this time slice is the position of the ice front on the Llŷn Peninsula and in Cardigan Bay compared with the limit identified by Garrard and Dobson (1974) from numerous borehole observations. Also of interest are the striking $\sim 100 \mathrm{~m}$ high crags just north of Tremadog, which appear to exert some control on ice flow, close to the transition zone between fast and slow ice-surface velocities of the Tremadog Glacier. The position of the sarns at the interfluves of outlet glaciers entering Cardigan Bay, as well as their orientation trending parallel to the direction of modelled flowlines, further supports the hypothesis that they have been streamlined by Welsh-sourced ice, and at least in part, represent interstream or medial moraine deposits.

It was during this time period that the Irish Sea Ice Stream was advancing through the Irish Sea Basin (Scourse, 1991; McCarroll et al., 2010; Chiverrell et al., 2013), coalescing with the Welsh Ice Cap (Fig. 5a). The confluence of these two glaciers would have led to high localised shear strain rates, with the flow units of differing velocities being forced along a path of convergence, inferred here as the Welsh "drift" limit mapped by Garrard and Dobson (1974). Direct mapping of present-day ice-sheet systems reveal ubiquitous longitudinal surface lineations called flow stripes or flow lines (Casassa et al., 1991; Casassa and Brecher, 1993; Fahnestock et al., 2000), which are sometimes interpreted as longitudinal foliation (Reynolds and Hambrey, 1988; Casassa et al., 1991; Casassa and Brecher, 1993; Hambrey and Dowdeswell, 1994; Glasser and Scambos, 2008; Glasser et al., 2011). Where glaciers converge, larger flow units tend to "pinch out" these structures where they meet smaller tributary glaciers (e.g. Glasser and Gudmundsson, 2012). Based on these contemporary analogues, it is speculated here that the western ends of the sarns would reflect this converging flow pattern, showing strong deflection southwards. Numerically modelled flow lines indicate that the Welsh Ice Cap was large enough to deflect advancing Irish Sea Basin ice onto the Llŷn Peninsula and away from the present-day west Wales coastline (Fig. 5a). This result supports observations from sedimentological sections along the Llŷn Peninsula that Welsh ice dominated in Tremadog Bay and eastern Cardigan Bay, leaving St. Tudwal's Peninsula as a key convergence point for both ice masses. However, the absence of the horizontal shear stress within the numerical model's first-order solution of the ice-flow equations means that the high localised shear strain rates predicted above are not replicated in this reconstruction (cf. Hubbard et al., 2009). More expansive submarine mapping of Cardigan Bay would also be needed to fully unlock the key ice dynamics in this region.

\subsection{Ice retreat}

The history and chronology of the Irish Sea Ice Stream has been relatively well constrained using numerous absolute dating techniques and Bayesian modelling, with retreat starting around 24.0-23.3 ka from the Isles of Scilly (cf. Chiverrell et al., 2013). Cosmogenic nuclide ages between 22.521.2 ka from the Llŷn Peninsula slightly predate general thinning of the Welsh Ice Cap and the exposure of mountain summits in mid-Wales between ca. 20-17 ka (Glasser et al., 2012). The general retreat pattern is complicated, however, by observations of repeated minor advances. Minor fluctuations of the Irish Sea Ice Stream have been recorded from Anglesey (Thomas and Chiverrell, 2007) and southeast Ireland (Thomas and Chiverrell, 2011), and the sharp-crested end moraines (set a) identified in this study north of Sarn Badrig 
also strongly suggest similar small-scale, ice-marginal oscillations of the Welsh Ice Cap.

Superimposed on these relatively low-order fluctuations are the more complex high-magnitude and non-linear response of the former ice masses to internal and external drivers. Bayesian modelling has given strong indication of a general slowdown in the rate of retreat of the Irish Sea Ice Stream once it reached the narrowing of the Irish Sea Basin between Wales and Ireland, with topographic confinement, "sticky spots", and change in bed slope all cited as probable reasons (Chiverrell et al., 2013). Similarly, new ice-sheet modelling of the Welsh Ice Cap has indicated deglaciation was punctuated by a phase of major, yet asymmetric readvance along its western margins ca. $21.15 \mathrm{ka} \mathrm{BP}$ (Fig. 6). This minor readvance captured in the model experiment coincides with a known Dansgaard-Oeschger event in the GISP2 climate record (Dansgaard et al., 1993; Grootes et al., 1993) - a short-lived cold episode that punctuated the last glaciation in the North Atlantic region. Analyses of the ice-rafted debris record from the British-Irish continental shelf indicate that such millennial-scale variability of palaeo ice-sheet dynamics in this region was a common phenomenon, with numerous, large flux events occurring during Marine Isotope Stages 3 and 2, in phase with known Dansgaard-Oeschger events (Scourse et al., 2009).

Model output reveals that the asymmetric response of outlet glaciers entering Cardigan Bay at this time is largely driven by the amplification of mass-balance variations between adjacent catchments, enhanced by eastward migration of the central ice-divide of the ice cap (Fig. 7). Similar, though more complex, dynamics in both spatial and temporal domains associated with ice divide migration have been inferred from the nearby Irish Ice Cap (Greenwood and Clark, 2009).

This dynamically-forced readvance episode captured in the model experiment raises another possibility for the formation of Sarn Badrig in particular: it is a composite feature, also representing morainic deposition at the frontal margin of the Mawddach outlet glacier. Figure 6 illustrates this variation; once Tremadog Bay is free of ice, the Mawddach Glacier is left unconstrained on its northern side and is thus free to advance across low-lying ground as far as Sarn Badrig. Although the relatively larger volume of Sarn Badrig could be a function of preservation, it may also reflect this composite development during readvances of the Welsh Ice Cap. A borehole at Mochras Point at the head of Sarn Badrig discovered a large number of different "drift" units up to $77 \mathrm{~m}$ below OD, some of which have been speculated to be of preDevensian age (e.g. O'Sullivan, 1971), lending support to repeated deliveries of glacial material from the Welsh hinterland. Unfortunately no conclusive ages have been found for these sediments (cf. Herbert-Smith, 1971). The interpretation, however, is complicated by the presence of an extensive Irish Sea-sourced diamicton overlying Welsh till at Tonfanau (Patton and Hambrey, 2009). The presence of well-preserved
Welsh-sourced glacial landforms in Tremadog Bay provides evidence that Irish Sea Basin ice must have impinged upon the coastline at Tonfanau prior to regional deglaciation, possibly when the Welsh Ice Cap and Irish Sea Ice Stream were confluent at the glacial maximum. Irish Sea Basin-sourced erratics deposited at Tonfanau may then have been subsequently incorporated and reworked into the upper till during readvance of the Mawddach outlet glacier (Fig. 6). This hypothesis may also account for the small proportion of Irish Sea erratics within Sarn Badrig (Foster, 1970).

In light of this hypothesis, rising sea level is not considered to be a driver for asynchronous retreat between adjacent outlet glaciers in Cardigan Bay since the similarity and shallow depth of the seabed around west Wales precludes any potential differences in calving rates or in the timing of retreat (Fig. 1). Also, despite initial and rapid eustatically forced retreat of Irish Sea Basin ice from the Celtic Sea (Scourse and Furze, 2001; Scourse et al., 2009; Chiverrell et al., 2013), coastal sections around the central and southern Irish Sea basin have consistently shown deglaciation occurred under terrestrial conditions (cf. McCarroll, 2001), in contrast to earlier interpretations of a glaciomarine model for deglaciation (Eyles and McCabe, 1989).

\section{Sequence of events}

Through interpretation of landform mapping, ice-sheet modelling and previously described sedimentological sections, the following sequence of events at the coalescent margin between the Irish Sea Ice Stream and Welsh Ice Cap is suggested for the Last Glacial Maximum (Fig. 8):

1. With the onset of widespread glaciation, Welsh-sourced ice rapidly inundated near-shore areas from proximal accumulation areas in the Welsh hinterland (Fig. 8a). Meanwhile further north, ice centres in Scotland, northern England and Northern Ireland were also growing, feeding ice into the Irish Sea Basin and initiating ice drainage, which would eventually stream as far south as the Scilly Isles (Scourse et al., 1990; Scourse, 1991; Hiemstra et al., 2006). In assuming a glacial origin for the sarns, these landforms were likely to have been present in Cardigan Bay throughout much of the Quaternary (Fig. 8a).

2. During the LGM, Welsh and Irish Sea ice coalesced; the topography of the Llŷn Peninsula, in combination with the rapidly expanding Welsh Ice Cap, acted as a major obstacle to south-flowing ice, leaving Tremadog Bay dominated by Welsh-sourced ice (Fig. 8b). As the Tremadog glacier reached maximum mass turnover, sediments at its base were being reworked, producing the streamlined bedforms observed within the bay and along the northern sarn edge. Abundant Irish Sea erratics exposed at Tonfanau indicate the Irish Sea Ice 

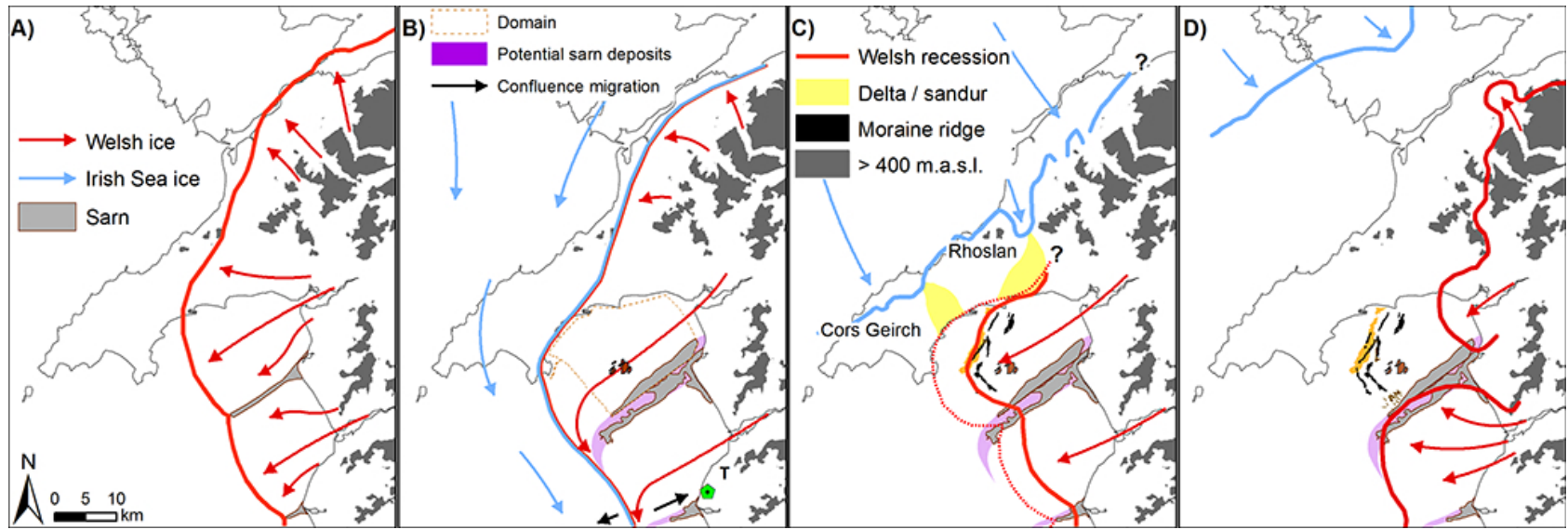

Figure 8. Proposed schematic sequence of events during the Last Glacial Maximum (LGM) in NW Wales (Welsh Ice: red; Irish Sea ice: blue): (A) Prior to advance of the Irish Sea Ice Stream, Welsh ice inundated the near-shore areas of Cardigan Bay. (B) At the LGM, Irish Sea and Welsh ice coalesced, the boundary defined by offshore borehole records (Garrard and Dobson, 1974) and geomorphological mapping on the Llŷn Peninsula (Thomas et al., 1998). Irish Sea erratics at Tonfanau (T) suggest possible impingement here after advance of Welsh ice (Patton and Hambrey, 2009). (C) During deglaciation, Welsh Ice still dominated Cardigan Bay, helping create the lacustrine delta terraces at Cors Geirch (Thomas et al., 1998). (D) Modelled output indicates a probable readvance during deglaciation of the Welsh Ice Cap ca. $21.15 \mathrm{ka}$ BP, enhanced by migration of the central ice divide and subsequent enlargement of the Mawddach Glacier catchment.

Stream impinged along the coastline here after a period of Welsh advance (Patton and Hambrey, 2009), possibly as a result of migration of the confluence zone between the two ice masses. Convergence of Welsh and Irish Sea ice flow units along the Irish Sea "drift" limit would probably have extended and deflected sarn-deposition southeastwards.

3. While the Irish Sea Ice Stream rapidly retreated from its unstable maximum extent with the onset of widespread deglaciation 24.0-23.3 ka (Scourse et al., 2009; Chiverrell et al., 2013), Welsh glaciers still dominated NE Cardigan Bay (Fig. 8c). Evidence for this includes the Cors Geirch terraces on the Llŷn Peninsula, which are the remnants of a glacial lake fed by Irish Sea Basin ice from the north, but dammed by Welsh-sourced ice to the south (Matley, 1936; Thomas and Chiverrell, 2007).

4. As deglaciation continued, moraines were laid down in Tremadog Bay during minor or seasonal readvances. The larger catchment of the Mawddach basin, coupled with a shift in the central ice divide, probably drove a minor readvance of ice from mid-Wales extending as far north as the ridge of Sarn Badrig during the Dansgaard-Oeschger event $\sim 21.15 \mathrm{ka} \mathrm{BP}$. In contrast, ice in Tremadog Bay retreated back to the present-day coastline at this time, during its overall recession towards the N Wales mountains (Fig. 8d).

5. With rapid marine transgression in Cardigan Bay following deglaciation, the sarns were submerged and were probably washed clean of fine glacial sediment by cur- rents within the intertidal zone. The present-day geomorphology on the shallow sea floor of Tremadog Bay (Fig. 2b) has been subsequently preserved beneath wave-base level.

\section{Conclusions}

New multibeam echo-sounder data collected from the eastern margin of the Irish Sea Basin reveal insights concerning glacier dynamics close to the confluence zone of the marineinfluenced Irish Sea Ice Stream and terrestrially based Welsh Ice Cap. For the first time, definitive glacial landforms associated with Welsh ice flowing offshore are presented. Through a combined approach using landform mapping, sedimentological interpretations and ice-sheet modelling, a regional reconstruction for complex flow and deglaciation for the eastern Irish Sea Basin is proposed. Superimposed on the low-order, small-scale oscillations of both ice masses, a general pattern of non-linear retreat is suggested for the Welsh Ice Cap, with a major asymmetric readvance attributed to ice-divide migration amplifying mass-balance variations between adjacent catchments. Our findings support others that show asymmetric and asynchronous marginal behaviour to be an emerging characteristic feature of the ice sheet centred over Britain and Ireland, in response to a range of internal and external drivers. Such higher-order dynamism underscores the importance for understanding ice-stream processes and dynamics at the scale of individual drainage basins - not only to more accurately reconstruct palaeo icesheet dynamics, but also to predict future centennial- to millennial-scale changes of polar ice masses. 
Modelled and geomorphological data indicate that the three sarns (large gravel ridges) in Cardigan Bay are composite features of frontal- and medial-moraine deposits that have been reworked through repeated advances of the Welsh outlet glaciers. Further sedimentological and bathymetric data collection in and around Cardigan Bay will serve to test the proposed reconstruction of events in this region.

Acknowledgements. This study was supported by a Joint Studentship (2K08/E108) provided by the British Geological Survey and Aberystwyth University via the BGS-University Funding Initiative, as well as a grant from the Climate Change Consortium of Wales. Swath bathymetry data used in this study was provided courtesy of the Maritime \& Coastguard Agency's UK Civil Hydrography Programme. Rhys Cooper is thanked for processing the multibeam data, and Nick Golledge for insightful comments on an earlier version of the MS. James Scourse, Ola Fredin and Greg Hancock are also thanked for their constructive reviews. T. Bradwell acknowledges support from the MAREMAP programme and publishes with permission of the Executive Director, BGS (NERC).

Edited by: G. Hancock

\section{References}

Bamber, J. L., Alley, R. B., and Joughin, I.: Rapid response of modern day ice sheets to external forcing, Earth Planet. Sc. Lett., 257, 1-13, 2007.

Benn, D. I. and Evans, D. J. A.: Glaciers and Glaciation, Arnold, London, 1998.

Benn, D. I. and Evans, D. J. A.: Glaciers and Glaciation, Hodder Education, London, 2010

Benn, D. I. and Owen, L. A.: Himalayan glacial sedimentary environments: a framework for reconstructing and dating the former extent of glaciers in high mountains, Quatern. Int., 97-98, 3-25, 2002

Bennett, M. P.: The morphology, structural evolution and significance of push moraines, Earth-Sci. Rev., 53, 197-236, 2001.

Bennett, M. R. and Glasser, N. F.: Glacial Geology: ice sheets and landforms, John Wiley and Sons, Chichester, 2009.

Bennett, M. R., Huddart, D., Glasser, N. F., and Hambrey, M. J.: Resedimentation of debris on an ice-cored lateral moraine in the high-Arctic (Kongsvegen, Svalbard), Geomorphology, 35, 2140, 2000.

Boulton, G. S.: Modern arctic glaciers as depositional models for former ice sheets, J. Geol. Soc. Lond., 128, 361-393, 1972.

Boulton, G. S.: A multiple till sequence formed by a late-Devensian Welsh ice cap: Glanllynau, Gwynedd, Cambria, 4, 10-31, 1977.

Boulton, G. S.: Push-moraines and glacier-contact fans in marine and terrestrial environments, Sedimentology, 33, 677-698, 1986.

Boulton, G. S., Van der Meer, J. J. M., Beets, D. J., Hart, J. K., and Ruegg, G. H. J.: The sedimentary and structural evolution of a recent push moraine complex: Holmstrombreen, Spitsbergen, Quaternary Sci. Rev., 18, 339-371, 1999.

Bowen, D., Phillips, F., McCabe, A., Knutz, P., and Sykes, G.: New data for the Last Glacial Maximum in Great Britain and Ireland, Quaternary Sci. Rev., 21, 89-101, 2002.
Bowen, D. Q.: The Pleistocene history of Wales and the borderland, Geol. J., 8, 207-224, 1973a.

Bowen, D. Q.: The Pleistocene succession of the Irish Sea, Proceedings of the Geologists' Association, 84, 249-272, 1973.

Bradwell, T., Stoker, M. S., Golledge, N. R., Wilson, C. K., Merritt, J. W., Long, D., Everest, J. D., Hestvik, O. B., Stevenson, A. G., Hubbard, A. L., Finlayson, A. G., and Mathers, H. E.: The northern sector of the last British Ice Sheet: Maximum extent and demise, Earth-Sci. Rev., 88, 207-226, 2008.

Bradwell, T., Sigurđsson, O., and Everest, J.: Recent, very rapid retreat of a temperate glacier in SE Iceland, Boreas, 42, 959-973, 2013.

Burgess, D. O. and Sharp, M. J.: Recent changes in areal extent of the Devon Ice Cap, Nunavut, Canada, Arct. Antarct. Alp. Res., 36, 261-271, 2004.

Calov, R., Ganopolski, A., Petoukhov, V., Claussen, M., and Greve, R.: Large-scale instabilities of the Laurentide ice sheet simulated in a fully coupled climate-system model, Geophys. Res. Lett., 29, 2216, doi:10.1029/2002GL016078, 2002.

Campbell, S. and Bowen, D. Q. (Eds.): The Quaternary of Wales, Geological Conservation Review, Nature Conservancy Council, Peterborough, 1989.

Casassa, G. and Brecher, H. H.: Relief and decay of flow stripes on Byrd Glacier, Antarctica, Ann. Glaciol., 17, 255-261, 1993.

Casassa, G., Jezek, K. C., Turner, J., and Whillans, I. M.: Relict flow stripes on the Ross Ice Shelf, Ann. Glaciol., 15, 132-138, 1991.

Chiverrell, R. C. and Thomas, G. S. P.: Extent and timing of the Last Glacial Maximum (LGM) in Britain and Ireland: a review, J. Quaternary Sci., 25, 535-549, 2010.

Chiverrell, R. C., Thrasher, I. M., Thomas, G. S. P., Lang, A., Scourse, J. D., Van Landeghem, K. J. J., McCarroll, D., Clark, C. D., Ó Cofaigh, C., Evans, D. J. A., and Ballantyne, C. K.: Bayesian modelling the retreat of the Irish Sea Ice Stream, J. Quaternary Sci., 28, 200-209, 2013.

Clark, C. D.: Mega-scale glacial lineations and cross-cutting iceflow landforms, Earth Surf. Proc. Land., 18, 1-29, 1993.

Clark, C. D., Hughes, A. L. C., Greenwood, S. L., Jordan, C., and Sejrup, H. P.: Pattern and timing of retreat of the last British-Irish Ice Sheet, Quaternary Sci. Rev., 44, 112-146, 2012.

Cofaigh, C. Ó., Dunlop, P., and Benetti, S.: Marine geophysical evidence for Late Pleistocene ice sheet extent and recession off northwest Ireland, Quaternary Sci. Rev., 44, 147-159, 2012.

Dansgaard, W., Johnsen, S. J., Clausen, H. B., Dahl-Jensen, D., Gundestrup, N. S., Hammer, C. U., Hvidberg, C. S., Steffensen, J. P., Sveinbjörnsdottir, A. E., Jouzel, J., and Bond, G.: Evidence for general instability of past climate from a 250-kyr ice-core record, Nature, 364, 218-220, 1993.

Evans, D. and Cofaigh, C. Ó.: Depositional evidence for marginal oscillations of the Irish Sea ice stream in southeast Ireland during the last glaciation, Boreas, 32, 76-101, 2003.

Evans, D. J. A.: Controlled moraines: origins, characteristics and palaeoglaciological implications, Quaternary Sci. Rev., 28, 183208, 2009.

Evans, D. J. A. and Twigg, D. R.: The active temperate glacial landsystem: a model based on Breiðamerkurjökull and Fjallsjökull, Iceland, Quaternary Sci. Rev., 21, 2143-2177, 2002.

Eyles, N. and McCabe, A. M.: The Late Devensian (<22,000 BP) Irish Sea Basin: The sedimentary record of a collapsed ice-sheet margin, Quaternary Sci. Rev., 8, 307-351, 1989. 
Eyles, N. and Rogerson, R. J.: A framework for the investigation of medial moraine formation: Austerdalsbreen, Norway, and Berendon Glacier, British Columbia, Canada, J. Glaciol., 20, 99-113, 1978a.

Eyles, N. and Rogerson, R. J.: Sedimentology of medial moraines on Berendon Glacier, British-Columbia, Canada - implications for debris transport in a glacierized basin, Geol. Soc. Am. Bull., 89, 1688-1693, 1978b.

Fahnestock, M. A., Scambos, T. A., Bindschadler, R. A., and Kvaran, G.: A millennium of variable ice flow recorded by the Ross Ice Shelf, Antarctica, J. Glaciol., 46, 652-664, 2000.

Forman, S. L., Marín, L., Van Der Veen, C., Tremper, C., and Csatho, B.: Little Ice Age and neoglacial landforms at the Inland Ice margin, Isunguata Sermia, Kangerlussuaq, west Greenland, Boreas, 36, 341-351, 2007.

Foster, H. D.: Sarn Badrig, a submarine moraine in Cardigan Bay, north Wales, Z. Geomorphol., 14, 473-486, 1970.

Garrard, R. A. and Dobson, M. R.: The nature and maximum extent of glacial sediments off the west coast of Wales, Mar. Geol., 16, 31-44, 1974.

Glasser, N. F. and Bennett, M. R.: Glacial erosional landforms: origins and significance for palaeoglaciology, Prog. Phys. Geogr., 28, 43-75, 2004.

Glasser, N. F. and Gudmundsson, G. H.: Longitudinal surface structures (flowstripes) on Antarctic glaciers, The Cryosphere, 6, 383 391, doi:10.5194/tc-6-383-2012, 2012.

Glasser, N. F. and Scambos, T. A.: A structural glaciological analysis of the 2002 Larsen B Ice Shelf collapse, J. Glaciol., 54, 3-16, 2008.

Glasser, N. F., Hambrey, M. J., Huddart, D., Gonzalez, S., Crawford, K. R., and Maltman, A. J.: Terrestrial glacial sedimentation on the eastern margin of the Irish Sea basin: Thurstaston, Wirral, Proceedings of the Geologists' Association The Geologists' Association, 112, 131-146, 2001.

Glasser, N. F., Hughes, P. D., Fenton, C., Schnabel, C., and Rother, $\mathrm{H} .: 10 \mathrm{Be}$ and 26Al exposure-age dating of bedrock surfaces on the Aran ridge, Wales: evidence for a thick Welsh Ice Cap at the Last Glacial Maximum, J. Quaternary Sci., 27, 97-104, 2012.

Glasser, N. F., Scambos, T. A., Bohlander, J., Truffer, M., Pettit, E., and Davies, B. J.: From ice-shelf tributary to tidewater glacier: continued rapid recession, acceleration and thinning of Röhss Glacier following the 1995 collapse of the Prince Gustav Ice Shelf, Antarctic Peninsula, J. Glaciol., 57, 397-406, 2011.

Greenwood, S. L. and Clark, C. D.: Reconstructing the last Irish Ice Sheet 2: a geomorphologically-driven model of ice sheet growth, retreat and dynamics, Quaternary Sci. Rev., 28, 31013123, 2009.

Grootes, P. M., Stuiver, M., White, J. W. C., Johnsen, S., and Jouzel, J.: Comparison of oxygen-isotope records from the GISP2 and GRIP Greenland ice cores, Nature, 366, 552-554, 1993.

Hambrey, M. J. and Dowdeswell, J. A.: Flow regime of the Lambert Glacier-Amery Ice Shelf system, Antarctica: structural evidence from Landsat imagery, Ann. Glaciol., 20, 401-406, 1994.

Hambrey, M. J., Bennett, M. R., Dowdeswell, J. A., Glasser, N. F., and Huddart, D.: Debris entrainment and transfer in polythermal valley glaciers, J. Glaciol., 45, 69-86, 1999.

Hambrey, M. J., Huddart, D., Bennett, M. R., and Glasser, N. F.: Genesis of "hummocky moraines" by thrusting in glacier ice: Ev- idence from Svalbard and Britain, J. Geol. Soc., 154, 623-632, 1997.

Herbert-Smith, M.: Palynology of the Tertiary and Pleistocene deposits of the Llanbedr (Mochras Farm) borehole, in: The Llanbedr (Mochras Farm) borehole, edited by: Woodland, A. W., Institute of Geological Sciences Report 71/18, 115 pp., 1971.

Hiemstra, J. F., Evans, D. J. a., Scourse, J. D., McCarroll, D., Furze, M. F. A., and Rhodes, E.: New evidence for a grounded Irish Sea glaciation of the Isles of Scilly, UK, Quaternary Sci. Rev., 25, 299-309, 2006.

Hubbard, A., Bradwell, T., Golledge, N., Hall, A., Patton, H., Sugden, D., Cooper, R., and Stoker, M.: Dynamic cycles, ice streams and their impact on the extent, chronology and deglaciation of the British-Irish ice sheet, Quaternary Sci. Rev., 28, 758-776, 2009.

Huddart, D.: The glacial history and deposits of the north and west Cumberland lowlands, in: Glacial Deposits of Great Britain and Ireland, edited by: Rose, J., Gibbard, P., and Ehlers, J., Balkema, Rotterdam, 157-167, 1991.

IPCC WG1: Climate Change 2007: The Physical Science Basis Contribution of Working Group 1 to the Fourth Assessment Report of the Intergovernmental Panel on Climate Change, edited by: Solomon, S., Qin, D., Manning, M., Chen, Z., Marquis, M., Averyt, K. B., Tignor, M., and Miller, H. L., Cambridge University Press, 2007.

Jehu, T. J.: The glacial deposits of western Caernarvonshire, T. Roy Soc. Edin., 47, 17-56, 1909.

King, E. C., Hindmarsh, R. C. A., and Stokes, C. R.: Formation of mega-scale glacial lineations observed beneath a West Antarctic ice stream, Nat. Geosci., 2, 585-588, 2009.

Knutz, P. C., Zahn, R., and Hall, I. R.: Centennial-scale variability of the British Ice Sheet: Implications for climate forcing and Atlantic meridional overturning circulation during the last deglaciation, Paleoceanography, 22, PA1207, doi:10.1029/2006PA001298, 2007.

Lambeck, K. and Purcell, A. P.: Sea-level change in the Irish Sea since the Last Glacial Maximum: constraints from isostatic modelling, J. Quaternary Sci., 16, 497-506, doi:10.1002/jqs.638, 2001.

Lundqvist, J.: Rogen (ribbed) moraine - identification and possible origin, Sediment. Geol., 62, 281-292, 1989.

Magnússon, E., Björnsson, H., Dall, J., and Pálsson, F.: Volume changes of Vatnajökull ice cap, Iceland, due to surface mass balance, ice flow, and subglacial melting at geothermal areas, Geophys. Res. Lett., 32, L05504, doi:10.1029/2004GL021615, 2005.

Matley, C. A.: A 50-foot coastal terrace and other lateglacial phenomena in the Lleyn Peninsula, Proceedings of the Geologists Association, 47, 221-223, 1936.

McCarroll, D.: Deglaciation of the Irish Sea Basin: a critique of the glaciomarine hypothesis, J. Quaternary Sci., 16, 393-404, 2001.

McCarroll, D., Stone, J. O., Ballantyne, C. K., Scourse, J. D., Fifield, L. K., Evans, D. J. A., and Hiemstra, J. F.: Exposure-age constraints on the extent, timing and rate of retreat of the last Irish Sea ice stream, Quaternary Sci. Rev., 29, 1844-1852, 2010.

Meier, M. F., Dyurgerov, M. B., Rick, U. K., O’Neel, S., Pfeffer, W. T., Anderson, R. S., Anderson, S. P., and Glazovsky, A. F.: Glaciers dominate eustatic sea-level rise in the 21 st century, Science, 317, 1064-1067, 2007. 
Merritt, J. W. and Auton, C. A.: An outline of the lithostratigraphy and depositional history of Quaternary deposits in the Sellafield district, west Cumbria, P. Yorks. Geol. Soc., 53, 129-154, 2000.

Mitchell, G.: The Pleistocene history of the Irish Sea: second approximation, Proceedings of the Royal Society of Dublin, 4, 181-199, 1972.

Moholdt, G., Hagen, J. O., Eiken, T., and Schuler, T. V.: Geometric changes and mass balance of the Austfonna ice cap, Svalbard, The Cryosphere, 4, 21-34, doi:10.5194/tc-4-21-2010, 2010.

Möller, P.: Rogen moraine: an example of glacial reshaping of preexisting landforms, Quaternary Sci. Rev., 25, 362-389, 2006.

Morgan, V. I., Jacka, T. H., Akerman, G. J., and Clarke, A. L.: Outlet glacier and mass budget studies in Enderby, Kemp, and Mac, Robsertson Lands Antarctica, Ann. Glaciol., 3, 204-210, 1982.

Nygård, A., Sejrup, H. P., Haflidason, H., Cecchi, M., and Ottesen, D.: Deglaciation history of the southwestern Fennoscandian Ice Sheet between 15 and 13 14C ka BP, Boreas, 33, 1-17, 2008.

Ó Cofaigh, C. and Evans, D. J. A.: Sedimentary evidence for deforming bed conditions associated with a grounded Irish Sea glacier, southern Ireland, J. Quaternary Sci., 16, 435-454, 2001.

Ó Cofaigh, C., Pudsey, C. J., Dowdeswell, J. A., and Morris, P.: Evolution of subglacial bedforms along a paleo-ice stream, Antarctic Peninsula continental shelf, Geophys. Res. Lett., 29, 1199, doi:10.1029/2002.GL014488, 2002.

O'Sullivan, K. N.: Log of the Llanbedr (Mochras Farm) borehole: Recent, Pleistocene and Tertiary, in: The Llanbedr (Mochras Farm) borehole, edited by: Woodland, A. W., Institute of Geological Sciences Report 71/18, 115 pp., 1971.

Ottesen, D. and Dowdeswell, J. A.: Assemblages of submarine landforms produced by tidewater glaciers in Svalbard, J. Geophys. Res., 111, F01016, doi:10.1111/j.15023885.2007.tb01251.x, 2006.

Ottesen, D., Dowdeswell, J. A., Landvik, J. Y., and Mienert, J.: Dynamics of the Late Weichselian ice sheet on Svalbard inferred from high-resolution sea-floor morphology, Boreas, 36, 286-306, 2007.

Patton, H. and Hambrey, M. J.: Ice-marginal sedimentation associated with the Late Devensian Welsh Ice Cap and the Irish Sea Ice Stream: Tonfanau, West Wales, Proceedings of the Geologists' Association, 120, 256-274, 2009.

Patton, H., Hubbard, A., Glasser, N. F., Bradwell, T., and Golledge, N. R.: The last Welsh Ice Cap: Part 1 - Modelling its evolution, sensitivity and associated climate, Boreas, 42, 471-490, $2013 \mathrm{a}$.

Patton, H., Hubbard, A., Glasser, N. F., Bradwell, T., and Golledge, N. R.: The last Welsh Ice Cap: Part 2 - Dynamics of a topographically controlled ice cap, Boreas, 42, 491-510, 2013b.

Reynolds, J. M. and Hambrey, M. J.: The structural glaciology of George VI Ice Shelf, Antarctic Peninsula, Brit. Antarct. Surv. B., 79, 79-95, 1988.

Saunders, G. E.: Reappraisal of glacial drainage phenomena in the Lleyn peninsula, Proceedings of the Geologists' Association, 79, 305-324, 1968a.

Saunders, G. E.: A fabric analysis of the ground moraine deposits of the Lleyn peninsula of south-west Caernarvonshire, Geol. J., 6, 105-118, 1968b.
Scourse, J. D.: Late Pleistocene stratigraphy and palaeobotany of the Isles of Scilly, Philos. T. R. Soc. B, 334, 405-448, 1991.

Scourse, J. D. and Furze, M. F. A.: A critical review of the glaciomarine model for Irish sea deglaciation: evidence from southern Britain, the Celtic shelf and adjacent continental slope, J. Quaternary Sci., 16, 419-434, 2001.

Scourse, J. D., Austin, W. E. N., Bateman, M. D., Catt, J. A., Evans, C. D. R., Robinson, J. E., and Young, J. R.: Sedimentology and micropalaeontology of glacimarine sediments from the central and southwestern Celtic Sea, Geological Society, London, 329347, doi:10.1144/GSL.SP.1990.053.01.19, 1990.

Scourse, J. D., Haapaniemi, A. I., Colmenero-Hidalgo, E., Peck, V. L., Hall, I. R., Austin, W. E. N., Knutz, P. C., and Zahn, R.: Growth, dynamics and deglaciation of the last British-Irish ice sheet: the deep-sea ice-rafted detritus record, Quaternary Sci. Rev., 28, 3066-3084, 2009.

Sharp, M.: Sedimentation and stratigraphy at Eyjabakkajökull - an Icelandic surging glacier, Quaternary Res., 24, 268-284, 1985.

Small, R. J.: Lateral Moraines of Glacier de Tsidjiore-Nouve form, development, and implications, J. Glaciol., 29, 250-259, 1983.

Smiraglia, C.: The medial moraines of Ghiacciaio Dei Forni, Valtellina, Italy - morphology and sedimentology, J. Glaciol., 35, 81-84, 1989.

Smith, B. and George, T. N.: North Wales. British Regional Geology, HMSO, London, 97 pp., 1961.

Synge, F. M.: The glacial succession in Caernarvonshire, Proceedings of the Geologists' Association, 75, 431-444, 1964.

Thomas, G. S. P. and Chiverrell, R. C.: Structural and depositional evidence for repeated ice-marginal oscillation along the eastern margin of the Late Devensian Irish Sea Ice Stream, Quaternary Sci. Rev., 26, 2375-2405, 2007.

Thomas, G. S. P. and Chiverrell, R. C.: Styles of structural deformation and syn-tectonic sedimentation around the margins of the late Devensian Irish Sea Ice Stream: the Isle of Man, Llyn Peninsula and County Wexford, in: Glacitectonics: A Field Guide, edited by: Phillips, E., Lee, J. R., and Evans, H. M., Quaternary Research Association, Pontypool, 59-78, 2011.

Thomas, G. S. P., Chester, D. K., and Crimes, P.: The Late Devensian glaciation of the eastern Lleyn Peninsula, North Wales: evidence for terrestrial depositional environments, J. Quaternary Sci., 13, 255-270, 1998.

van der Veen, C. J.: Polar ice sheets and global sea level: how well can we predict the future?, Global Planet. Change, 32, 165-194, 2002.

Van Landeghem, K. J. J., Wheeler, A. J., and Mitchell, N. C.: Seafloor evidence for palaeo-ice streaming and calving of the grounded Irish Sea Ice Stream: Implications for the interpretation of its final deglaciation phase, Boreas, 38, 119-131, 2009.

Whittow, J. B. and Ball, D. F.: North-west Wales, in: The glaciations of Wales and adjoining areas, edited by: Lewis, C. A., Longman, London, 21-58, 1970. 